\title{
POTASSIUM RELEASE FOLLOWING ADMINISTRATION OF SUCCINYLCHOLINE IN CHRONICALLY URAEMIC MONKEYS
}

\author{
Davin R. CoOK, M.D., A. Benedict Cosimi, M.D., \\ and Max W. Hammonds, M.D.f
}

\section{INTRODUGTION}

THE SAFETY OF ADMINISTERING SUCCTNYLCHOLNE to the uraemic surgical patient is controversial. Scattered case reports suggest hyperkalaemia following administration of this drug as a cause of cardiac arrest or serious ventricular arrhythmias in uraemic patients.1.7 Recent elinical studies, however', question whether succinylcholine is indeed the cause of these serious arrhythmias, ${ }^{3,4}$ In a previous report we noted no difference in the pattern of potassium release following administration of succinylcholine to normal or to acutely uraemic monkeys. ${ }^{5}$ Whether a change occurs in the pattern of potassium release after a latent period of uraemia was not defined. Hence, we have examined changes in serum potassium following administration of succinylcholine in chronically uraemic monkeys. In a supplementary study the effect of second doses of succinylcholine was noted.

\section{MerHods}

Eleven thesus monkeys of average weight $2.3 \mathrm{Kg}$ were studied during a three week period of chronic uraemia. Six non-uraemic monkeys served as controls. The method devised to maintain these animals with a blood urea nitrogen (BUN) consistently in the range of $100-250 \mathrm{mg}$ per cent without utilizing dialysis is briefly as follows. ${ }^{\text {. }}$

The monkeys were sedated with phencyclidine and a laparotomy was performed using sterile surgical technique. One ureter was ligated and the contralateral ureter was catheterized through ureterostomy with a $\# 8$ paediatric feeding tube. The catheter was brought through the muscle wall posteriorly, tunneled subcutaneously, and exteriorized through a stab wound in the skin near the midline posterior. The laparotomy wound was closed and a plaster bandage was applied to prevent subsequent damage to the catheter. It was then possible to remove the catheter plug to allow ureteral drainage when desired without further anaesthesia.

The animals were studied on days 10 and 20 . Endoctracheal intubation with 3.5$4.0 \mathrm{~mm}$ I.D. uncuffed tubes was accomplished under phencyclidine sedation. The anaesthesia used was halothane (0.5-1.0 per cent) in 60 per cent nitrons oxide

- Major, USAF, MC, Staff Anaesthesiologist.

tMajor, USAF, MC, Staft General Surgeon.

tCaptain, USAF, MC, Mesident in Auesthesiology.

Department of Surgery, Anesthesiology Service and General Surgery Service, Wilford Hall USAF Medical Center, Lackland Air Force Base, Texas 78236.

No Reprints avajlable.

634

Canad. Anaesth. Soc. J, vol. 19, no. 6, November 1972 
with oxygen, ventilation being controlled with a Bird Mark IV ventilator to maintain the $\mathrm{pH}$ constant at \pm 0.02 from controls.

A femoral arterial cannula was placed. Arterial blood gas samples were drawn for $\mathrm{P}_{\mathrm{CO}_{2}}, \mathrm{P}_{\mathrm{O}_{2}}$ and $\mathrm{pH}$ determination on a Radiometer Blood Gas Analyzer. Arterial samples were drawn for blood urea nitrogen, creatinine, and potassium. Succinylcholine, $1 \mathrm{mg} / \mathrm{Kg}$, was then injected into the femoral vein under direct vision. Blood samples were drawn in non-heparinized syringes for potassium determinations at $3,5,7,10$ and 15 minutes. A 10-minute sample was also obtained for $\mathrm{pH}, \mathrm{P}_{\mathrm{rO}_{2}}$, and $\mathrm{P}_{\mathrm{O}_{2}}$ determinations.

The blood samples were transferred to heparinized test tubes and centrifuged. The potassium concentration of the plasma was determined on an Instrumentation Laboratories Flame Photometer incorporating an automatic diluter. The precision for the technique was assessed at $\pm 0.05 \mathrm{mEq} /$ liter. BUN and creatinine were determined by standard auto-analyzer techniques.

\section{RESULTS}

The mean BUN, creatinine, and potassium values for each time period for the control and uraemic groups are shown in Table I. The death of some monkeys precluded study of every animal at both 10 and 20 days; therefore, statistical analysis was made by means of the Students' unpaired test.

The mean BUN, creatinine, and potassium levels at 10 and 20 days of uraemia were significantly elevated when compared to the control group. In addition, the BUN and creatinine of the 20-day group were significantly higher than the 10-day group $(P<0.05)$.

Table II shows changes in potassium in three monkeys studied at both 10 days and 20 days. The largest change from initial potassium value was $1.7 \mathrm{mEq} / \mathrm{liter}$, occurring in a monkey after 10 days of uraemia. This rise is significantly greater than the maximal mean change of all the monkeys $(P<0.05)$.

The coefficient of linear correlation of the maximal change in potassium value was calculated for all monkeys as a group. The coefficient of correlation of the maximal change in potassium versus BUN level was 0.22 and for the maximal change in potassium versus the initial potassium value was 0.04 .

Three monkeys, uraemic for 20 days, were rechallenged with succinylcholine following the initial study. This resulted in a maximal increase in potassium of 0.3 to $0.4 \mathrm{mEq} /$ liter over the preceding 15 -minute value.

\section{Discussion}

The mean changes in potassium in the chronically uraemic groups are comparable to those seen in normal man and in acutely uraemic monkeys during nitrous oxide-oxygen-halothane anaesthesia ${ }^{5.7}$ Like Miller, et $a l^{3}{ }^{3}$ and Koide and Waud, ${ }^{4}$ we saw no significant increase in mean potassium levels after administration of succinylcholine to control and uraemic groups. However, the serum potassium of one monkey rose $1.7 \mathrm{mEq} /$ liter above the control value. Powell and Golby ${ }^{8}$ likewise noted marked increases in the potassium levels of some acutely uraemic rats following succinylcholine. 


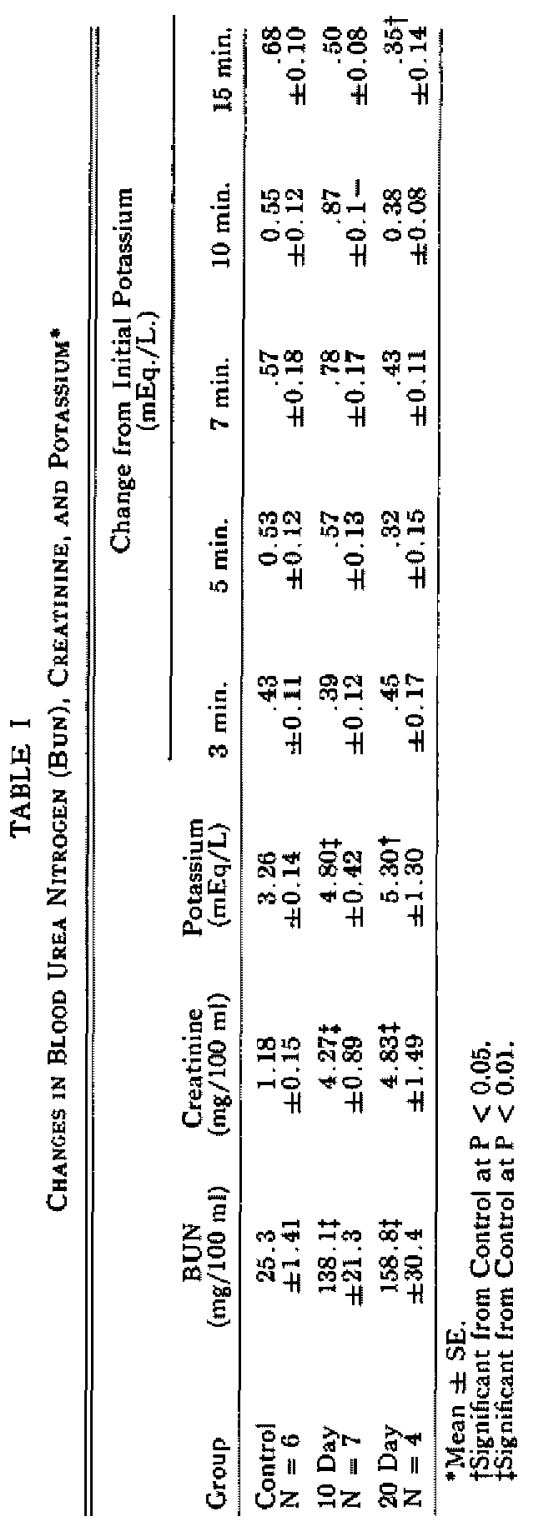


TABLE II

Changes in blood urea Nitrogen (bun) and Potassium in Uhaemic Monkeys at Different Time Pertods

\begin{tabular}{|c|c|c|c|c|c|c|c|c|}
\hline \multirow[b]{2}{*}{ Group } & \multirow[b]{2}{*}{ Animal } & \multirow[b]{2}{*}{ BUN } & \multirow{2}{*}{$\begin{array}{l}\text { Potassium } \\
(\mathrm{mEq} / \mathrm{L})\end{array}$} & \multicolumn{5}{|c|}{$\begin{array}{l}\text { Change Irom Initial Potassiura } \\
\qquad(\mathrm{mEq} / \mathrm{L})\end{array}$} \\
\hline & & & & $3 \mathrm{~min}$ & $5 \mathrm{~min}$ & 7 min. & $10 \mathrm{~min}$. & $15 \mathrm{~min}$ \\
\hline \multirow{3}{*}{10 Day } & $\mathrm{H}-8$ & 104 & 5.0 & 0.1 & 0.6 & 0.9 & 1.1 & 0.2 \\
\hline & $58-Z$ & 100 & 5.6 & 1.0 & 1.3 & 1.7 & 1.3 & 0.5 \\
\hline & $60-Z$ & 220 & 6.6 & 0.1 & 0.3 & 0.6 & 0.9 & 0.8 \\
\hline \multirow{3}{*}{$20 \mathrm{Day}$} & H-8 & 130 & 5.2 & 0.8 & 0.7 & 0.7 & 0.4 & 0.1 \\
\hline & $58-Z$ & 250 & 8.9 & 0.0 & 0.0 & 0.3 & 0.2 & 0.1 \\
\hline & $60-Z$ & 130 & 4.3 & 0.6 & 0.2 & 0.2 & 0.3 & 0.6 \\
\hline
\end{tabular}

The potassium response in our monkeys was more exaggerated at 10 days of uraemia than at 20 days. Koide and Waud ${ }^{4}$ noted that the potassium response to succinylcholine in uraemic patients was not modified by pretreatment with curare. This leads us to speculate that perhaps chronically elevated BUN is a "membrane stabilizer," blunting potassium release following succinylcholine. We found no correlation of the potassium response with either the degree of uraemia or with the initial potassium value. We could not substantiate the suggestion of Koide and Waud ${ }^{4}$ that second doses of succinylcholine might produce a more exaggerated response.

We conclude that although the potassium response to succinylcholine in the acutely and chronically uraemic monkey is usually no different from that in nonuraemic monkeys, an occasional exaggerated response can occur. This has been confirmed by Powell and Golby." To date, it is impossible to predict under what circumstances this exaggerated response may occur. We therefore advise continued caution in the use of succinylcholine in uraemic patients.

\section{SUMMarY}

The change in potassium response following succinylcholine was studied in eleven Rhesus monkeys after 10 and 20 days of persistent uraemia. We noted no significant increase in mean potassium levels after administration of succinylcholine in the uraemic groups when contrasted with a control group. However, the serum potassium in one animal rose $1.7 \mathrm{mEq} /$ liter, which is a significant rise $(P<0.05)$. The potassium response did not change with increasing duration of uraemia, nor did it correlate with either the degree of uraemia nor with the initial potassium value. Since it is impossible to predict under what circumstances an exaggerated response may occur we advise continued caution in the use of succinylcholine in uraemic patients.

\section{Résumé}

Sur onze singes Rhesus, maintenus entre 10 et 20 jours en urémie permanente, nous avons étudié les changements des taux de potassium en réponse à l'administration de 
succinylcholine. Chez les urémiques comparés aux témoins, nous n'avons pas observé de modifications importantes des taux de potassium après l'administration de succinylcholine. Toutefois, chez un animal, le taux de potassium sérique s'est slevé de $\mathbf{1 . 7}$ $\mathrm{mEq} /$ litre ce qui constitue une élévation importante $(\mathrm{P}<0,05)$. Cette réponse du potassium n'a pas change avec la prolongation de l'urémie, pas plus qu'avec l'importance de l'urémie ou la valeur initiale du potassium. Etant donné qu'il est impossible de prévoir à quel moment il se produira une réponse exagérée du potassium à l'administration de succinylcholine, nous conseillons une surveillance étroite continuelle des malades urémiques à qui l'on administre de la succénylcholine.

\section{REFERENCES}

1. Rотн, F. \& Wuтнасі, $\mathrm{H}$. The clinical importance of hyperkalaemia following suxamethonium administration. British Journal of Anaesthesia, 41:311 (1969).

2. PowELI, J.M. Suxamethonium-induced hyperkalaemia in a uraemic patient. British journal of Anaesthesia 42: 807 (1970).

3. MiLLk, R.D., WAY, W.L. Hamieton, W.K. \& LaYzEa, R.B. Succinylcholine in patients with renal failure? Anesthesiology 36; 139 (1972).

4. KODE, M. \& WAun, B.E. Serum potassium concentrations after succinylcholine in patients with renal failure. Anesthesiology 36: 297 (1972).

5. Cook, D.R. \& Cosmi, A,B, Potassium release following succinylcholine in acutely uremic monkeys. Anesthesiology 36: 297 (1972)

6. Cosmi, A.B., BHOWn, B.G., Haines, R.J., \& Cook, D.R. Maintenance of chronic uremia in monkeys with dialysis. (In preparation.)

7. Weintanue, H.B., Hersterreamp, D.V., \& Cooperman, L.H. Changes in plasma potassium concentration after depolarizing blockers in anaesthetized man. British Journal of Anaesthesia 41 : 1048 ( 1969$)$.

8. PowrLL, J.N. \& GourY, M. The pattems of potassium liberation following a single dose of suxamethonium in normal and uraemic rats. British Journal of Anaesthesia 43: 662 (1971). 